
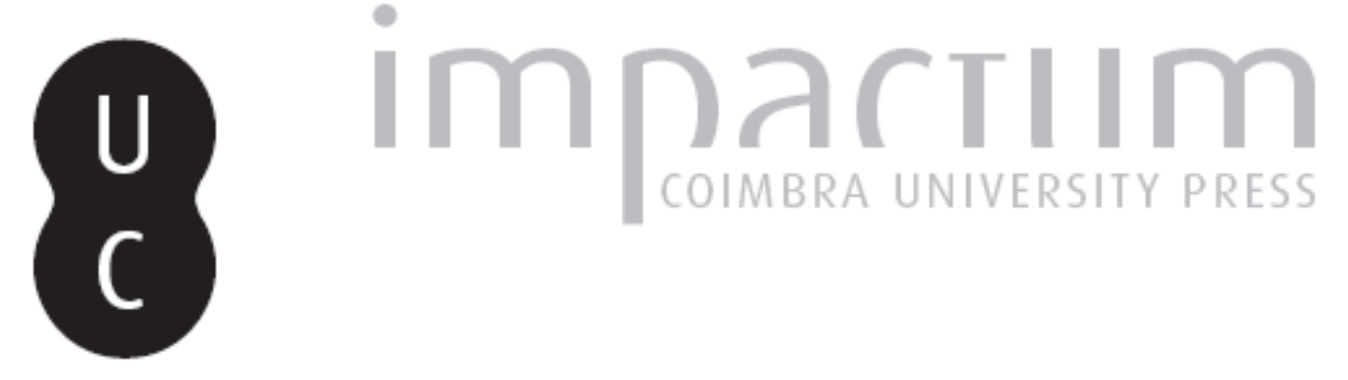

\title{
«Não destruas por causa da comida a obra de Deus»: restrições e recomendações alimentares na legislação sinodal portuguesa (séculos XIV a XVI)
}

Autor(es): $\quad$ Cândido, Guida da Silva

Publicado por: Centro de História da Sociedade e da Cultura

URL persistente:

URI:http://hdl.handle.net/10316.2/39363

DOI:

DOI:http://dx.doi.org/10.14195/1645-2259_14_5

Accessed : $\quad$ 26-Apr-2023 16:05:19

A navegação consulta e descarregamento dos títulos inseridos nas Bibliotecas Digitais UC Digitalis, UC Pombalina e UC Impactum, pressupõem a aceitação plena e sem reservas dos Termos e Condições de Uso destas Bibliotecas Digitais, disponíveis em https://digitalis.uc.pt/pt-pt/termos.

Conforme exposto nos referidos Termos e Condições de Uso, o descarregamento de títulos de acesso restrito requer uma licença válida de autorização devendo o utilizador aceder ao(s) documento(s) a partir de um endereço de IP da instituição detentora da supramencionada licença.

Ao utilizador é apenas permitido o descarregamento para uso pessoal, pelo que o emprego do(s) título(s) descarregado(s) para outro fim, designadamente comercial, carece de autorização do respetivo autor ou editor da obra.

Na medida em que todas as obras da UC Digitalis se encontram protegidas pelo Código do Direito de Autor e Direitos Conexos e demais legislação aplicável, toda a cópia, parcial ou total, deste documento, nos casos em que é legalmente admitida, deverá conter ou fazer-se acompanhar por este aviso.

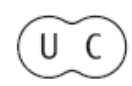




\section{4 \\ 2014}

\section{evista de História da Sociedade e da Cultura}

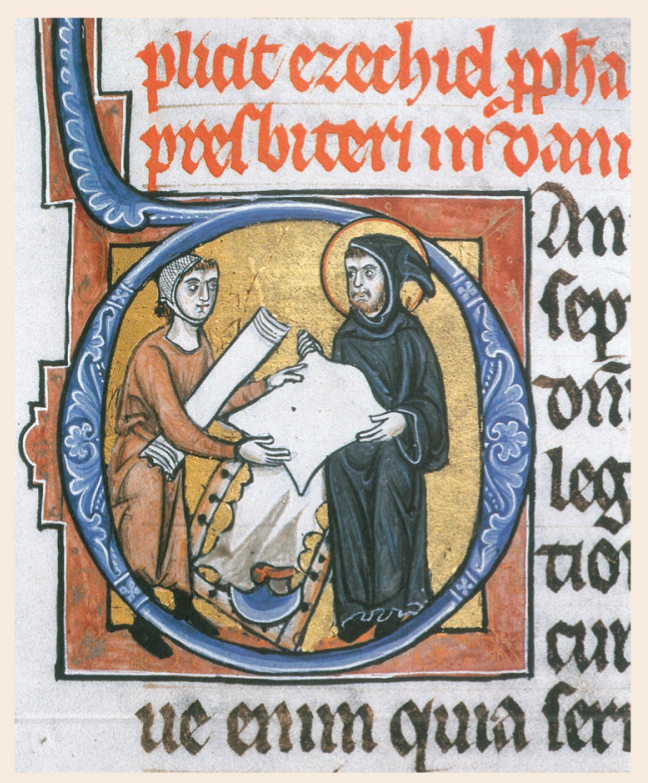

Centro de História da Sociedade e da Cultura Universidade de Coimbra 


\title{
«Não destruas por causa da comida a obra de Deus» Restrições e recomendações alimentares na legislação sinodal portuguesa (séculos XIV a XVI)
}

\author{
Guida da Silva Cândido \\ Investigadora do Centro de Estudos Clássicos e Humanísticos da \\ Faculdade de Letras da Universidade de Coimbra \\ Divisão de Cultura da Câmara Municipal da Figueira da Foz \\ guida.silva.candido@gmail.com \\ Texto recebido em/Text submitted on: 13.05.2014 \\ Texto aprovado em/Text approved on: 24.09.2014
}

\section{Resumo/Abstract:}

Após uma introdução sobre Sínodos - descrição, objetivos e intervenientes - e as celebrações no nosso território durante a época medieval, procura-se, com base na análise de fontes documentais de natureza eclesiástica, mais concretamente através de um conjunto de nove sínodos realizados entre os séculos XIV e XVI, avaliar o papel da alimentação - e suas manifestações - no quotidiano da sociedade medieval. Distinguem-se as restrições e recomendações alimentares dirigidas ao clero e aos leigos e, de entre estes, aos cristãos e aos cristãos em convívio com judeus e mouros. A análise à legislação sinodal permite aferir sobre a incontornável relevância, prestígio e transcendência dos alimentos durante a Idade Média e dos aspetos determinantes na conduta da Igreja Católica face ao reconhecimento da alimentação enquanto sinal de poder.

After an introduction on Synods - description, goals and participants - and the celebrations conducted in our territory during the Middle Ages, this paper attempts to assess the role of food - and its expressions - in the daily life of the medieval society. This study is based on the analysis of documental sources of an ecclesiastical nature, namely through a set of nine Synods held between the 14th and 16th centuries. A distinction is made between the dietary restrictions and recommendations directed to the clergy and to laypeople. Of these, a distinction is also made between Christians and Christians in contact with Jews and Moors. The analysis of the synodal legislation makes it possible to ascertain the indisputable relevance, prestige and transcendence of food during the Middle Ages, as well as the determining factors in the conduct of the Catholic Church, in view of the recognition of food as a symbol of power.

Palavras chave/Keywords:

Sínodos; Alimentação; Idade Média; Leigos; Clero.

Synods; Food; Middle Ages; Laypeople; Clergy. 


\section{Apresentação}

«Conformando-nos com o direito, mandamos e defendemos», expressão recorrente na legislação sinodal e objeto de análise neste trabalho, reflete com clareza o objetivo de tais demandas. A documentação sinodal constitui um instrumento identificador de práticas religiosas desviantes que expressam a proibição e condenação destas pela igreja, de forma objetiva e autoritária, com base nas suas leis. Daí a referência a diversos aspetos negativos da sociedade, uma vez que o objetivo final é a correção dos abusos praticados por todos os indivíduos.

Pretende-se, com esta análise, reconhecer a importância da alimentação nas práticas e leis da Igreja, através das recomendações e restrições impostas por este órgão, durante a época medieval portuguesa, no período restrito dos séculos XIV e XV $\mathrm{XV}^{1}$. A fonte estudada, o Synodicon Hispanum II, reúne o texto de vinte e nove sínodos que compreendem os séculos XIII a XVI. Contudo, o presente estudo debruça-se apenas sobre nove, omitindo os textos de origem latina e todos os outros sínodos que não contêm referências ao tema aqui proposto - a alimentação².

Em observação está a legislação sinodal respeitante a Braga dos anos de 1333, 1402, 1477 e 1505; Évora, de 1420-23, confirmada em 1457; Guarda, de 1500; Lisboa, de 1403; Porto, de 1496; e finalmente da Administração Eclesiástica de Valença do Minho, de 1444. Pese embora o número reduzido de sínodos analisados, as informações neles contidas retumbam de forma inequívoca a mensagem que a Igreja medieval proclama. Porém, a fiabilidade da execução das diretrizes legisladas carece de comprovação efetiva. Em última análise, existe sempre a dúvida se, de facto, tudo o que está escrito é realmente consumado.

As restrições impostas pela Igreja, na temática abordada, definem o comportamento que se espera de religiosos e seculares e destes, em particular,

Excecionalmente inclui-se a análise do Sínodo de Braga de 1505.

2 O«Synodicon hispanum» é uma edição crítica dos sínodos das dioceses espanholas e portuguesas celebrados depois do Concílio IV de Latrão em 1215 até ao Concílio de Trento em 1563. A edição compreende até ao momento a publicação de dez volumes, sendo objeto deste estudo o volume II. 
também no seu convívio "com os judeus e com as judias inimigos de nosso senhor Jhesu Christo e da sua sancta fé católica"'.

Nas recomendações examinadas distinguem-se as normativas - jejum e dízima - comuns a todas as classes e grupos da estrutura social medieval e as dirigidas, distintamente, ao clero e aos seculares. A Igreja vigia as práticas religiosas e a fé dos seus seguidores, "punindo os que atentavam contra os bens das igrejas, os que nelas se comportavam mal, os que não cumpriam penitências e jejuns"4.

Com base nesses documentos da Igreja, a leitura possível do quotidiano de tempos medievos, espelha um conjunto de comportamentos que justifica a escolha do título deste trabalho. Inspirada na belíssima e esclarecedora passagem do livro dos Romanos, 14-20, «Não destruas por causa da comida a obra de Deus», a obra de Deus, da Santa Madre Igreja Católica, é o ponto fulcral e primordial da vivência humana. Nada a pode desviar dessa missão, nem sequer o princípio básico de alimentar o corpo. Alimentar o espírito será a empresa dos fiéis cristãos.

\section{Sínodos}

\subsection{Descrição}

As designações sínodo e concílio têm uma aplicação comum durante os primeiros tempos da história da Igreja. Só a partir do século IV se verifica uma atribuição distinta de significados, nomeadamente com as grandes reuniões ecuménicas - os concílios - como Nicéia em 325. As assembleias de bispos de uma província, região ou diocese são identificadas como sínodos $^{5}$. Os sínodos diocesanos surgem após o século VI, sendo os mais antigos Llandaff (560), Auxerre (578) e Huesca (598).

3 GARCIA Y GARCIA, António (ed.) - Synodicon Hispanum II, Portugal. Madrid: Biblioteca de Autores Cristianos, 1982, p. 130.

4 COELHO, Maria Helena da Cruz e HOMEM, Armando Luís de Carvalho - A estruturação social in SERRÃO, Joel e MARQUES, António de Oliveira (dir.) - Nova História de Portugal - Portugal em definição de fronteiras do Condado Portucalense à crise do século XIV. Lisboa: Editorial Presença, 1996, p. 299.

5 LOYN, H. R. (org.) - Dicionário da Idade Média. Rio de Janeiro: Jorge Zahar Editor, 1990, p. 771. 
Os sínodos diocesanos medievais mais não são que reuniões dos bispos com os seus clérigos e representantes das ordens religiosas. Os clérigos que não podem estar presentes têm de se fazer representar por procuradores. Nada obriga na legislação canónica que laicos assistam a estas celebrações, contudo, é muito provável que as autoridades civis e locais se façam representar ${ }^{6}$. E embora se atribua o vocábulo sínodo de forma ampla, como bem refere Isaías da Rosa Pereira, em técnica jurídica, o sínodo é a reunião do bispo com o seu presbitério, onde só ele tem um papel legislador, cabendo aos sacerdotes apenas a voz consultiva. As normas emanadas e promulgadas pelo prelado confinam-se ao território da diocese. Para além das constituições sinodais ou estatutos sinodais, resultam ainda destas cerimónias as Actas, das quais constam as diversas cerimónias, nomeadamente o sermão sinodal, encomendado a um pregador, teólogo ou canonista, com características de grande orador?

A hierarquia comum nos sínodos tem o bispo a ocupar o lugar de primazia, seguido de párocos e abades. A partir do século XI, em pleno período gregoriano, com novas estruturas nos cabidos, nascem outras figuras atuantes nas assembleias sinodais. Estas celebrações alcançam novo impulso com a referida reforma gregoriana, depois de um período de dormência durante os séculos X e XI. Antes, durante a época carolíngia, são já frequentes como ferramenta normativa do direito comum das decisões emanadas nos concílios e dos próprios sínodos, bem como instrumento formativo do clero e do exercício das suas funções pastorais ${ }^{8}$.

A relevância da figura do bispo é determinante pelo facto de o sínodo se definir como um órgão consultivo e não deliberativo. Depende pois, da forte personalidade do bispo, a influência exercida por este junto do seu clero e fiéis. Desse carisma resulta a aplicação das orientações sinodais dirigidas a religiosos e seculares - bem como das práticas corretas pelo clero

6 CANTELAR RODRÍGUEZ, Francisco - El «Synodicon hispanum», espejo de la España medieva., Anuario de Historia de la Iglesia. 17 (2008) 338.

7 PEREIRA, Isaías da Rosa - "Os sermões de André de Resende nos sínodos de Évora de 1534 e de 1565 e as falas de Francisco de Melo no sínodo de 1534”, in Humanitas, Instituto Estudos Clássicos da Faculdade de Letras da Universidade de Coimbra, v. $43 / 44$ (1992) 186.

8 RODRIGUES, Manuel Augusto - Recensões e notas de leitura. Revista de História das Ideias. 5 (1984) 426-427. 
local das leis da Igreja, nomeadamente no que concerne à administração dos sacramentos 9 .

Embora a Igreja, durante a Baixa Idade Média, aplique leis nas suas congregações, só o IV Concílio de Latrão, reunido na cidade de Roma em 1215 - o mais determinante na época medieval e um dos mais importantes da História da Igreja Católica - concebe leis acerca dos sínodos diocesanos com alcance universal ${ }^{10}$.

Entre os séculos XIII e XV, os sínodos de Lisboa e de outras regiões portugueses são descritas com semelhanças às cortes nobres. Ou seja, funcionam como um tribunal onde se debate os modos de punir os infratores e estimular a união entre a comunidade. Sendo que, entre os séculos XIV e XV, a demanda formativa do bispado articula conselhos e prescrições com o objetivo principal da correção, em particular da conduta pecaminosa dos clérigos incontidos ${ }^{11}$.

Para conhecer a vida humana, desde o nascimento até à morte, é determinante a leitura das constituições sinodais. Elas ocupam-se da vida religiosa e da vida social, espelhando o modus operandi medieval. Através da sua interpretação é possível conhecer as regras sobre a conduta do clero, nomeadamente em relação à frequência de tabernas e prática de caça, bem como regulamentação sobre o relacionamento judaico-cristão e restrições nas comunidades judaicas. A legislação emanada do referido concílio reflete-se nos sínodos portugueses visados neste estudo.

\subsection{Legislação sinodal portuguesa}

A tradição de sínodos medievais no nosso território confirma-se na presente documentação agora observada. O Synodicon Hispanum II abarca 73 sínodos lusos, apesar de apenas existir notícia da celebração de 44, e destes, apenas 29 se apresentarem transcritos. O maior número respeita ao século XIV, existindo um número mais reduzido tanto no século XIII como

\footnotetext{
9 Ibidem, p. 427.

${ }^{10}$ TEODORO, Leandro Alves - "O comprometimento moralizante dos sínodos portugueses entre os séculos XIV e XV”, in Portuguese Studies Review, 21 (1) (2013) 8.

${ }^{11}$ Ibidem, p. 18.
} 
no século XV. No entanto, não existe aqui uma relação direta de quantidade e relevância, sobretudo porque a descrição histórica não é rigorosa por falta de representatividade estatística ${ }^{12}$.

A obrigação do bispo é a celebração de um sínodo anual na sua diocese, de acordo com as emanações do Concílio IV de Latrão. Porém, a regularidade destas celebrações não obedece a essas rígidas diretivas. Não obstante, a documentação existente é certamente inferior ao número de reuniões realizadas durante a época medieval ${ }^{13}$. Contudo, assembleias com estas características passam a ser comuns, entre os séculos XIV e XV, no nosso território. Nas zonas menos próximas dos centros urbanos, as procedências resultantes destes encontros, constituem a única fonte de informação que os párocos possuem que denunciam os males decorrentes dos pecados ${ }^{14}$.

Ganha peso o poder do bispo, como acima se indica, pois o seu poder está relacionado com o campo da legislação, fabricando as constituições sinodais como uma ferramenta legislativa, regulando as diferentes facetas da vida «indo do vestuário ao lúdico [tornando-se] um amplo corpus jurídico». Revestem-se, as constituições sinodais, de uma dupla função. Além de determinar as regras corretivas das ações dos leigos, procura definir as admoestações específicas para conduzir o religioso na sua obrigação do cumprimento dos ofícios sacramentais ${ }^{15}$.

Neste estudo está em observação, como já se indicou, a legislação sinodal respeitante a Braga dos anos de 1333 (Braga 9), 1402 (Braga 21), 1477 (Braga 26) e 1505 (Braga 28); Évora, de 1420-23, confirmada em 1457 (Évora 6); Guarda, de 1500 (Guarda 1), Lisboa, de 1403 (Lisboa 11); Porto, de 1496 (Porto 11) e finalmente da administração eclesiástica de Valença do Minho, de 1444 (Valença do Minho 1).

Braga é representada, no Synodicon Hispanum II, com vinte e oito sínodos, quatro dos quais merecem análise no respeitante à temática abordada, sendo que o sínodo de 1505 é incluído nesta organização de sínodos medievais por representar muitos aspectos e problemáticas desse período histórico.

${ }^{12}$ GARCIA Y GARCIA, António (ed.) - Synodicon Hispanum II..., cit., p. XVII- XVIII.

${ }^{13}$ CANTELAR RODRÍGUEZ, Francisco - El «Synodicon hispanum»..., cit., p. 338.

14 TEODORO, Leandro Alves - "O comprometimento moralizante dos sínodos portugueses entre os séculos XIV e XV”, p. 8.

${ }^{15}$ Ibidem, p. 9. 
O sínodo de D. Gonçalo Pereira, de 6 de setembro de 1333, é o primeiro escrito em português nessa diocese. Celebrado após visita pastoral, as suas constituições contêm referências a sínodos anteriores e "insistem nos problemas da residência e da vida moral dos clérigos e religiosos da diocese"16.

D. Martinho Afonso Pires da Charneca, a 5 de abril de 1402, celebra o sínodo que determina penas para religiosos e poderosos sobre comportamentos interditos nas igrejas ${ }^{17}$.

As constituições sinodais mais importantes para o período medieval são publicadas no sínodo de Braga pelo arcebispo D. Luís Pires, em 11 de dezembro de $1477^{18}$, o que se justifica pelo espírito reformador do seu autor.

Por último, em relação à diocese Bracarense, apresenta-se o sínodo de D. Diogo de Sousa, de 15 de dezembro de 1505, com disposições legislativas herdadas do sínodo do Porto de 1496, de onde foi transferido, justificando a opção de incorporar este sínodo na cronologia medieval ${ }^{19}$.

Conhece-se a existência de oito sínodos da diocese de Évora. A promulgação que aqui interessa referir corresponde à constituição sobre o dízimo do gado, emitido por D. Pedro de Noronha (1420-23) e confirmada a 7 de setembro de 1457 por D. Vasco Perdigão ${ }^{20}$.

No que respeita à diocese egitaniense, o sínodo de D. Pedro Vaz Gavião, de 12 de maio de 1500, é o mais antigo que se conhece, havendo com toda a certeza legislação sinodal anterior por neste se referirem a constituições precedentes. A sua relevância é tanto ou mais determinante pelo facto de ser o único sínodo do período medieval conhecido para aquela diocese e também pelo percurso do seu legislador, o capelão-mor do rei D. Manuel ${ }^{21}$.

É de Lisboa o sínodo mais antigo de que há notícia ${ }^{22}$. Da época medieval conhecem-se sete mas admite-se a existência de um número bastante superior. O sínodo em análise, de D. João Afonso Esteves de Azambuja,

${ }^{16}$ GARCIA Y GARCIA, António (ed.) - Synodicon Hispanum II..., cit., p. 47.

${ }^{17}$ Ibidem, p. 61-62.

${ }^{18}$ Pelos assuntos abordados e a forma linguística e literária aplicada, semelhante ao português utilizado pelos cronistas. Ibidem, p. 73-74.

${ }^{19}$ Ibidem, p. 138-139.

${ }^{20}$ Ibidem, p. 215.

${ }^{21}$ Ibidem, p. 223-224.

${ }^{22}$ Celebrado a 1 de maio de 1191, pelo bispo D. Soeiro Anes (1185-1209). Ibidem, p. 283. 
celebrado a 13 de janeiro de 1403, é o único da diocese de Lisboa do século $\mathrm{XV}$ que sobreviveu até à atualidade. Nele, o legislador recupera constituições sinodais de antecessores, nomeadamente em relação a comportamentos normativos de cristãos em convívio com judeus e mouros ${ }^{23}$. D. Diogo de Sousa, anteriormente referido como bispo de Braga, é para ali transferido após a sua passagem pela diocese do Porto e leva consigo as mesmas ideias legislativas emanadas no sínodo que celebra nesta diocese em 24 de agosto de 1496. É autor do mais antigo catecismo português impresso ${ }^{24}$.

A Administração Eclesiástica de Valença do Minho sofre diversas vicissitudes durante o período abordado. No essencial, importa registar que, embora não seja por direito uma diocese, é-o na prática, por ter administradores que exercem atos de jurisdição espiritual e temporal na sua Sé.

O sínodo de D. João Afonso Ferraz I, de 5 de fevereiro de 1444, é único nesta administração eclesiástica, embora a sua intenção inicial seja a celebração de sínodos anuais ${ }^{25}$.

O alvo de qualquer sínodo é o prevaricador. As constituições não visam o reconhecimento das boas práticas por parte de laicos e religiosos que, voluntariamente, cumprem os seus deveres. Pretendem sim, atingir, independentemente do estatuto ou condição, aquele que erra, que infringe, que não age de acordo com a conduta estipulada pelas leis eclesiásticas. Conscientes do seu poder, os legisladores determinam, sancionam e corrigem. O que se procura é que os cristãos atuem na terra de acordo com o santos no céu: limpeza, virtude e louvores divinos. Virtudes que se exigem de forma mais consistente aos eclesiásticos, pois de acordo com a Santa Igreja, devem ser santos porque consagram a dedicam a sua vida a Deus. Daí a necessidade de reuniões frequentes para reforma dos costumes e busca de santidade pelos clérigos ${ }^{26}$.

Eis agora as restrições e recomendações!

${ }^{23}$ Ibidem, p. 283-284, 317-318.

${ }^{24}$ D. Diogo de Sousa é considerado um dos prelados mais brilhantes da sua época pelo papel determinante que teve nas dioceses por onde passa, imprimindo o seu cunho de cultura e disciplinador eclesiástico. Ibidem, p. 354.

${ }^{25}$ Ibidem, p. 417-424.

${ }^{26}$ PEREIRA, Isaías da Rosa - "Os sermões de André de Resende nos sínodos de Évora de 1534 e de 1565 e as falas de Francisco de Melo no sínodo de 1534”, p. 190-191. 


\section{Restrições}

A vivência quotidiana do homem medieval é marcada pela Igreja. A religião acompanha-o desde o berço até à sepultura de forma indelével. Começa com o batismo - oito dias após o nascimento - e termina com o sacramento da extrema-unção, quando há oportunidade para isso.

A influência e orientação que a Igreja católica impõe não se propagam tanto por manifestações de fé da sociedade medieval, mas mais pela necessidade de respostas que esta proporciona. A ignorância científica de então leva a essa busca de respostas, de conforto espiritual que a Igreja oferece, nem sempre de forma desprendida e voluntária. Desempenha, bastas vezes, um papel castrador e repressivo.

\subsection{Ao clero}

Os sínodos em análise permitem verificar que a aplicação de interdições e restrições é transversal a leigos e religiosos, embora em certas situações com características diferentes. Contudo, o clero não está isento do cumprimento de determinadas diretivas que controlam o seu comportamento, uma vez que também eles respondem perante Deus. E é por muitas vezes falharem no seu relacionamento com Deus que os clérigos são admoestados. Pelo não cumprimento das suas obrigações eclesiásticas, deixando as igrejas sem missas e demais celebrações; os paroquianos sem sacramentos e enterramentos para gozarem dos prazeres terrenos como a caça e a frequência de tabernas.

No sínodo de Braga 26, o arcebispo D. Luís Pires deixa bem explícita a interdição dos seus religiosos se deslocarem com cães e aves de caça nas vilas e de os deixarem entrar nas igrejas e coros, à semelhança de vulgares caçadores ${ }^{27}$. Ora, esta constituição reflete a vivência do homem religioso da época. Beneficiado pelo seu estatuto social, o clérigo usufrui de disponibilidade para as cousas terrenas, para o ócio e as distrações. $\mathrm{O}$ alto clero procura as mesmas recreações e diversões que a nobreza. E nestas está

${ }^{27}$ GARCIA Y GARCIA, António (ed.) - Synodicon Hispanum II..., cit., p. 111-112. 
incluída a caça de montaria e cestraria. Conforme se observa, esta restrição de caçar pode ser anulada, de forma pontual, "por algũua evidente necessidade de aliviamento de infirmidade ou tristeza"28.

O desvio de funções eclesiásticas por parte do clero, não será certamente exclusivo das suas "fugas" para a atividade da caça. Contudo, os seus superiores hierárquicos não deixam de referir o incumprimento das funções eclesiásticas com os fiéis cristãos, bem como "elles mesmos clerigos perdem as Oras e as nom rezam" 29 . A frequência das tabernas - para comer e beber pelos religiosos deve ser também interdita, "salvo quando andarem caminho ou não tiverem pousada no lugar onde estiverem que então a necessidade os releva" ${ }^{30}$. As interdições ao clero contemplam ainda o uso de armas, pois a Igreja combate com "lagrimas e orações". Podem apenas transportar consigo, como é de resto prática comum de todo o homem medieval, um pequeno cutelo para "cortar as unhas, pam, carne e fruita e outra vianda",31.

\subsection{Aos seculares}

Ainda que as restrições indicadas nos sínodos visem também os religiosos, elas são em maior número para a gente laica. $\mathrm{O}$ povo obedece às leis civis e às leis da Igreja. Molda a sua vida e condu-la de acordo com esses códigos para se livrar de sanções e estigmas.

Para controlar a moral e a ética, tem o clero a obrigação de estipular os limites e definir as barreiras do que é próprio e impróprio. E ainda que, segundo Oliveira Marques, a Igreja medieval não se destine apenas a lugar de culto, por aí também se desenrolarem reuniões e diversões, têm de se balizar estas ações. Na igreja dançam, ouvem trovadores e jograis; representam autos; comem, bebem; dormem; falam alto; riem; discutem e trabalham, inclusive alguns clérigos ${ }^{32}$. Contudo, a legitimidade destes atos é posta em

${ }^{28}$ Ibidem, p. 112.

${ }^{29}$ Ibidem, p. 112.

${ }^{30}$ Ibidem, p. 257.

${ }^{31}$ Ibidem, p. 122.

${ }^{32}$ MARQUES, A. H. de Oliveira - A sociedade medieval portuguesa. Aspectos da vida quotidiana, $4 .^{\text {a }}$ ed. Lisboa, 1982, p. 168. 
causa pelas constituições sinodais. D. Martinho Afonso Pires da Charneca, no sínodo de Braga de 1402, em relação à prática de dormir e comer dentro das igrejas, admoesta "todollos condes, ricos homeens, infanções, cavaleiros, scudeiros e outras quaeesquer pessoas de qualquer stado e condiçom [...] se abstenham de pousarem nem comerem nos dictos moosteiros e egrejas nem tomem nem mandem tomar dellas pam nem vinho, carne nem cevadas, palhas, ervas, ferrãaes nem outros beens". Mesmo quando essas pessoas afirmem fazê-lo "per mandado dos abades, priores, rectores dellas" 33 .

A mesma matéria é abordada e objeto de restrição no sínodo assinado por D. Luís Pires, na Sé de Braga, em 1477, uma vez que "a egreja de Deus hé casa de oraçom e lugar de sanctidade [...] muito menos deve seer conssentido que [...] sejam postas mesas e se façam convites de comer e beber [...] muitas vezes se contece poerem os odres e pechees, emfusas e cantaros com vinho e auga sobre os sanctos altares". Todos os que não cumprem ficam "sub penna d'escuminhom e maldiçom eterna, [...] salvo se for alguum clerigo, emquanto celebrar alguum trintairo emçarrado, ou alguum omiziado" ${ }^{34}$.

Igual intenção é proclamada na diocese egitaniense por D. Pedro Vaz Gavião, salvaguardando a exceção dos clérigos, após algumas celebrações religiosas, poderem "tomar vinho e fruta, contanto que seja no coro ou tesouro nas igrejas onde os houver. E isto mesmo defendemos que em as ditas igrejas se não ponha trigo, nem cevada, vinho, azeitona, ervanços, cebolas, alhos, nem outras semelhantes cousas" 35 .

Com o propósito de regulamentar o comportamento adequado dos cristãos quanto à prática dos ritos religiosos próprios desta época, dirige-se o bispo D. Luís Pires a estes, no sínodo de 1477, interditando-os de vender ou comprar em tabernas e boticas, durante o decorrer das missas, "porque os dias do sancto dominguo e das festas de nosso Senhor Jhesu Christo com suas oytavas e de nossa senhora sancta Maria e dos outros dias que a sancta madre Egreja ordenou e manda guardar de todo lavor foram assy instituidos pera os fiiees christãaos se ocuparem em visitar as egrejas e ouvir missa e

\footnotetext{
${ }^{33}$ GARCIA Y GARCIA, António (ed.) - Synodicon Hispanum II..., cit., p. 63.

${ }^{34}$ Ibidem, p. 96-97.

${ }^{35}$ Ibidem, p. 239.
} 
a pregaçom e os oficcios divinos". Estão pois proibidos "os especieiros e enxerqueiros, regatões, padeiras, verceiras, taverneiras, fruyteiras e mostardeiras, e assy qualquer outros vendedeiros" de praticarem os seus ofícios vendendo pão, carne, pescado, vinho, hortaliças, frutas, erva mostarda ou qualquer outro alimento, senão por alguma "emfermidade ou legitima e onesta necessidade, nomeadamente a venda de mezinhas a doentes, em qualquer hora do dia" ${ }^{36}$.

Sobre os mesmos alimentos recai a proibição, anos mais tarde e em diocese diferente, clarificando o leitor sobre a coerência e longevidade das restrições, interdições e recomendações sinodais. No caso, o sínodo celebrado por D. Pedro Vaz Gavião, acrescenta ainda a proibição de carniceiros e magarefes nos dias de festa e domingos, matarem, esfolarem ou talharem carne publicamente ${ }^{37}$.

Verifica-se uma particular preocupação com o mester dos carniceiros e enxerqueiros $^{38}$. As interdições a este ofício aparecem, em alguns sínodos, destacadas, ameaçando a pena de excomunhão em caso de desobediência: "todollos carniceiros e enxarqueiros [...] nom matem bois, vacas, carneiros nem porcos nem cabras nem cabrões nem cortem a carne delles", recomendando que o façam na véspera desses dias, em grande quantidade, para que possa a carne ser usada posteriormente nos dias a guardar ${ }^{39}$.

\subsection{Aos cristãos em convivência com judeus e mouros}

As ligações conciliadoras dos cristãos para com os judeus transformar-se-ão no decurso dos séculos históricos. Contudo, existiu sempre um contacto singular com o Judaísmo procurando, em última instância, familiarizar-se com ele enquanto teologia, do que abarcar uma compreensão da sua índole religiosa ${ }^{40}$. Na Idade Média o judaísmo e o islamismo são tolerados pela

${ }^{36}$ Ibidem, p. 127-128.

${ }^{37}$ Ibidem, p. 239.

${ }^{38}$ Aquele que retalha e põe para secar ou defumar a carne das reses.

${ }^{39}$ GARCIA Y GARCIA, António (ed.) - Synodicon Hispanum II..., cit., p. 128-129.

${ }^{40}$ GOMES, Saul António - "A questão judaica nos autores medievais portugueses", Cadernos de Estudos Sefarditas, n. ㅇ 9, 2009, p. 95. 
Igreja Católica. O grau de tolerância para com estas comunidades é de tal ordem que lhes é permitido participar em algumas manifestações religiosas da Igreja Católica, nomeadamente a festa do Corpo de Deus, na primeira quinta-feira a seguir ao Pentecostes, onde são admitidos na procissão, exibindo os seus trajes, músicas e danças ${ }^{41}$.

O corpus legislativo régio português sobre os judeus é extenso. Nessa documentação exibe-se um discurso que expressa a visão dos legisladores face aos judeus. No campo da legislação canónica portuguesa, nomeadamente na legislação sinodal, torna-se transparente a «subjacência implícita de uma lógica apologista e, necessariamente, controversista, face aos judeus $\rangle^{42}$. A própria Igreja lembra-lhes permanentemente o privilégios de os aceitarem e ao seus credos: «Achamos que os judeus e judias, nom contentes das liberdades e privilegios e defenssom que recebem, em que som conservados e soportados pella benignidade da piedosa sancta madre Egreja e pollas ordenações do Regno, mais sobejamente se estendem e devassam em muitas cousas em vituperio e desprezo da sancta fé catholica e grande escandallo dos fiiees chhristãaos.» ${ }^{43}$. Contudo, esta mesma Igreja procura a conversão de judeus e mouros e limita o seu convívio com os fiéis cristãos. Melhor dizendo, restringe aos seus fiéis a convivialidade com seguidores dos diferentes credos. Pois os judeus e judias são "inimigos de nosso senhor Jhesu Christo e da sua sancta fé católica". As constituições sinodais exigem, a todos os fiéis cristãos, "em virtude d'obediencia e sub penna d'excuminhom [...] que nom comam nem bebam nem dormam em cama nem morem com elles nem comam da carne morta e degollada per elles nem vãao a seus esposouros nem vodas nem circoncissõoes de seus filhos" ${ }^{\prime 4}$. Igualmente estão os cristãos proibidos de os convidar para as suas festas $^{45}$ e de tomarem das suas mezinhas ${ }^{46}$. Como refere Saul Gomes no seu

${ }^{41}$ COELHO, Maria Helena da Cruz - A festa - a convivialidade in MATTOSO, José (dir.) e SOUSA, Bernardo Vasconcelos (coord.) - História da Vida Privada em Portugal. Lisboa: Círculo de Leitores, 2010, p. 163.

${ }^{42}$ GOMES, Saul António - "A questão judaica nos autores medievais portugueses", p. 103.

${ }^{43}$ GARCIA Y GARCIA, António (ed.) - Synodicon Hispanum II..., cit., p. 129.

${ }^{44}$ Ibidem, p. 310-131.

${ }^{45}$ Ibidem, p. 328-329.

${ }^{46}$ Ibidem, p. 336. 
estudo, e tomando por base o sínodo presidido por D. João Martins Soalhães, em 1307, era expressamente proibido aos cristãos e cristãs, servirem em casa de judeus, aos domingos e feriados, mesmo no caso das amas cristãs ao serviço de judias, o que levanta esta questão importante, do ponto de vista antropológico, do aleitamento de crianças judias, por amas cristãs, liberto de interdição religiosa, excetuando então os domingos e dias feriados ${ }^{47}$. E embora não esteja contemplado entre os sínodos agora objeto de estudo, cabe aqui referência ao sínodo de 1403, presidido por D. João Esteves da Azambuja, no qual é referida uma constituição que proibia os judeus e mouros que viviam entre cristãos de comerem carne em público na Quaresma, sextas-feiras e nos outros dias em que os cristãos devem jejuar ${ }^{48}$.

Os destinatários da legislação sinodal são, em última análise, os católicos. Não obstante essa verdade, os legisladores acabam por se dirigir também aos judeus e mouros, da mesma forma que o fazem aos cristãos no seu convívio com estes. E determinam, em certas e pontuais constituições, proibições impostas a estes grupos sociais, nomeadamente sobre a abertura dos seus comércios e o desenrolar dos seus ofícios, dentro das comunidades cristãs, durante os "dias dos sanctos dominguos e festas de nosso Senhor Jhesu Christo e de nossa senhora sancta Maria e de sam Joham Baptista e dos apostollos", recomendando aos seus fiéis que, caso os judeus e mouros não cumpram, se apartem destes e "nem lhes conprem nem vendam nem lhes falem nem dem foguo nem loguo atee que os judeus façam emmenda do dicto pecado" 49 .

Restringem também a possibilidade de judeus e mouros, que vivem fora das judiarias e mourarias ${ }^{50}$, praticarem os seus ofícios, cozinharem e

${ }^{47}$ GOMES, Saul António - "A questão judaica nos autores medievais portugueses", p. 104.

${ }^{48}$ Ibidem, p. 104.

${ }^{49}$ GARCIA Y GARCIA, António (ed.) - Synodicon Hispanum II..., cit., p. 129-130.

${ }^{50}$ As autoridades determinam a existência de enclaves para proteção da restante comunidade. Aqui se incluem os bairros de judeus e mouros, normalmente fixadas as judiarias nas imediações dos centros urbanos e as mourarias apartadas dos centros das cidades e vilas. As autoridades procuraram, para ambas as comunidades as coabitação com a maioria cristã. COSTA, Adelaide Pereira Millán da - O espaço urbano in MATTOSO, José (dir.) e SOUSA, Bernardo Vasconcelos (coord.) - História da Vida Privada em Portugal. Lisboa: Círculo de Leitores, 2010, p. 31. 
comerem carne em público durante o tempo quaresmal e todos os outros dias indicados aos cristãos para a prática do jejum ${ }^{51}$.

\section{Recomendações}

A distinção entre o que são restrições, interdições e recomendações na legislação sinodal não é fácil de estabelecer, não estando isento de um determinado grau de subjetividade. Cabe ao leitor, de forma individual, apreender que, muitas vezes, umas andam acopladas às outras.

As recomendações pressupõem, maioritariamente, a proibição de algo, de uma prática ou comportamento. Porém, devido a questões organizacionais, propõe-se essa distinção, figurando no campo das recomendações aquelas que são consideradas normativas, transversais aos diferentes grupos e classes sociais - jejuns e dízimas - e as pontuais, que surgem na sequência da necessidade de precaver situações que não estão determinadas à priori, por desconhecimento dos grupos atuantes ou por inexistência de factos que a elas obrigam.

\subsection{Normativas}

\subsubsection{Do jejum}

A mensagem evangélica propõe a aceitação de todos os alimentos como um dom da Providência divina. Apesar disso, ao longo da sua História, a Igreja Católica assume uma certa renúncia à carne pela sua simbologia relacionada com a violência, a morte, a natureza física e sexual. Esta renuncia é menos visivel no clero secular que, exceptuando o período de abstinência quaresmal, a aceita com naturalidade incluindo-a na sua alimentação ${ }^{52}$. Na Idade Média, o jejum de carne abrange um período bem mais longo do

${ }^{51}$ GARCIA Y GARCIA, António (ed.) - Synodicon Hispanum II..., cit., p. 329.

${ }^{52}$ FLANDRIN, Jean-Louis et MONTANARI, Massimo (dir.) - História da alimentação, Dos primórdios à Idade Média. Lisboa: Terramar, 1998, p. 267-268. 
que as atuais recomendações quaresmais, impondo-se como uma forma de identidade religiosa mais do que busca de purificação pessoal.

Não passa despercebido ao leitor da legislação sinodal em análise, as posições distintas dos legisladores face à regulamentação do calendário litúrgico de jejum junto das suas comunidades. Se num extremo se identifica a necessidade de definir com rigor os dias a jejuar, por estarem em falta os fiéis cristãos na sua obediência, no outro, indicam-se, por excesso de zelo, um número incorreto e aumentado para esse ritual católico. Na primeira situação encontra-se a diocese de Braga em 1477, considerando o seu arcebispo, D. Luís Pires, que existe incumprimento das normas de jejum, muito por negligência do próprio clero que não ensina aos fiéis cristãos quais os dias a jejuar, ficando dessa forma muitos dias "por jejunar e aas vezes comem carne nos dictos dias e jejunam em outros que lhes nom mandam jejũar e esto polla negligencia e culpa dos reictores e curas que nom querem aprender o que ham de fazer, ensinar e mandar o poboo, parece-nos seer necessário declararmos aqui quaaes som os dias em que os christãaos devem jejunar"’33. Para que não haja lugar a dúvidas, enumeram-se todos os dias do calendário do ano em que deverá ser praticado o jejum, acrescentando também os dias que não sendo de jejum efetivo, devem ser sujeitos a algumas restrições - não comer carne - mas em que se admite, ao contrário dos anteriormente referidos, a ingestão de ovos, leite, manteiga e queijo. Prescreve-se a necessidade de não comer fígado ao sábado, mesmo em dias de não jejum. O incumprimento destas recomendações implica a excomunhão para os prevaricadores ${ }^{54}$.

D. Diogo de Sousa, enquanto arcebispo do Porto e de Braga, toma a mesma posição, fixando os dias de jejum a praticar pelos fiéis cristãos, com ligeiras diferenças, omitindo ou acrescentado alguns dias e festas de santos e recomendando que cada abade faça jejuar o dia do orago da sua igreja. No sínodo de Braga, a festa dos Reis; São Martinho de Dume (arcebispo que foi de Braga); São Frutuoso (arcebispo que foi de Braga); Apóstolos Filipe e Jacobo; São Miguel e São Martinho são indicados como dias a guardar

\footnotetext{
${ }^{53}$ GARCIA Y GARCIA, António (ed.) - Synodicon Hispanum II..., cit., p. 130.

${ }^{54}$ Ibidem, p. 131.
} 
mas a não jejuar ${ }^{55}$. Por direito canónico estão obrigados, os cristãos, a jejuar durante as celebrações principais que são a Quaresma, o Natal, a véspera de Ascenção, as festas de Nossa Senhora - Purificação, Anunciação, Assunção e Nascimento - os Apóstolos e Todos os Santos ${ }^{56}$.

A prova de que comportamentos, disposições, leis, recomendações e interdições têm, em todo a hora e em todo tempo, leituras e desfechos díspares, verifica-se nestas mesmas constituições sinodais. Se os anteriores legisladores entendem a necessidade de lembrar aos fiéis cristãos os seus deveres de jejum, nos quais têm falhado, os seguintes, por vezes, apontam a necessidade de aligeirar esse procedimento. Não obstante, o cristão faltoso no cumprimento do jejum, nos dias determinados pelos cânones, incorre em pecado mortal.

D. Pedro Vaz de Gavião, na Sé da Guarda, celebra o sínodo que elenca os seguintes dias de jejum obrigatórios: "a vigília de Natal, e de Páscoa, e da Ascensão, e Pentecostes, e as vigílias das cinco festas de nossa Senhora, [...] a vigília de Todos-os-Santos, e as vigílias e festas principais dos Apóstolos, tirando de são João Evangelista e de Santiago e de são Filipe que vêm entre solenidades do Natal e Páscoa e Pentecostes, em os quais tempos de necessidade não há nenhum jejum obrigatório. Também de necessidade de jejum é a vigília de são João Baptista e a vigília de são Lourenço, e as quatro têmporas do ano, e assim toda a Quaresma". O jejum começa à meia-noite da véspera e estende-se até à meia-noite do dia, perfazendo um período de vinte e quatro horas ${ }^{57}$.

Considera também D. João Afonso Ferraz, na Administração Eclesiástica de Valença do Minho, que os abades e reitores exageram nos dias que indicam para jejum aos seus fiéis cristãos e, por serem em demasia, não cumprem nem esses nem os que pelos santos cânones devem cumprir. Assim, determina que se jejue de acordo com o calendário os seguintes dias de santos: Purificação; Apostolo S. Mateus; Páscoa com três dias; Anunciação de Nossa Senhora;

${ }^{55}$ TEODORO, Leandro Alves - "A regulação das solenidades religiosas nas terras portuguesas (sécs. XIV - XV)” in Confluenze, Università di Bologna, vol. 6, n. ${ }^{\circ}$ 1, 2014, p. 70.

${ }^{56}$ GARCIA Y GARCIA, António (ed.) - Synodicon Hispanum II..., cit., p. 179-181; 403-405.

${ }^{57}$ Ibidem, p. 238-239. 
Parasceve; Pentecostes; S. João Batista; S. Pedro e S. Paulo; Santa Maria Madalena; Santiago; Santa Maria da Neve; S. Lourenço; Transfiguração; Assunção de Santa Maria; Apóstolo Matias; S. Simão e Judas; Omnium Sanctorum; Santo André; Santa Maria antes do Natal; S. Tomé; N. S. da Conceição e o Natal com três dias ${ }^{58}$.

\subsubsection{Da dízima}

Os bens, rendimentos e privilégios do clero são por demais evidentes durante o período medieval. As suas fontes de receita incluem os rendimentos diretos da terra, os que resultam da sua categoria de senhorios e diversos impostos, nomeadamente o dízimo eclesiástico, ou dízima - pagamento da décima parte dos frutos. Com tradição longínqua, herdada de disposições do Antigo Testamento, e vulgarizada entre os cristãos do Ocidente, começa por ser uma contribuição voluntária que ganha carácter de obrigatoriedade como contributo eclasiástico.

A dízima incide sobre a propriedade - reais ou prediais - e sobre o trabalho - pessoais ou conhecenças. Possui, desta forma, uma abrangência total. A forma de pagamento não se reveste de caráter uniforme, variando de acordo com a diocese ou a própria freguesia, possuindo, bastas vezes, uma natureza arbitrária, cuja finalidade é o aumento dos proventos sobre este direito ${ }^{59}$. Por via da regra, é o rendeiro ou arrematante que recebe os produtos da dízima e os entregam às instituições eclesiásticas. Estas dividem-na em três partes: a terça episcopal para o bispo; um terço para o clero da instituição e a outra para a fábrica da igreja ${ }^{60}$. Este imposto suscita, ao longo dos tempos, diversas querelas e questões polémicas entre o clero e o povo, motivadas pela execução do pagamento pontual dos direitos eclesiásticos.

${ }^{58}$ Ibidem, p. 440-441.

${ }^{59}$ SERRÃ̃, Joel (dir.) - Dicionário de História de Portugal, vol. II. Porto: Livraria Figueirinhas, 1992, p. 328-329.

${ }^{60}$ COELHO, Maria Helena da Cruz e HOMEM, Armando Luís de Carvalho - A estruturação social..., cit., p. 239. 
São, por isso, matéria abundante na maioria dos sínodos medievais, dos quais os agora analisados não são exceção ${ }^{61}$.

Quando o arcebispo D. Diogo de Sousa celebra o sínodo de 1505 em Braga, emite duas constitiuções sobre o pagamento da dízima - sobre o gado e frutos da terra - em tudo semelhantes às que havia feito escrever, no Porto, nove anos antes ${ }^{62}$.

Nestas constituições sinodais pode o leitor aferir a importância que o pagamento da dízima representa tanto para a Igreja que a recebe, como para o freguês que a paga. Na realidade é difícil ao camponês, com todos os impostos, rendas e encargos que tem, conseguir rendimentos significativos do seu trabalho. O pagamento da décima sobre os animais encontra alguns obstáculos de cariz prático quando o número de cabeças não é igual a dez ou seus múltiplos. Quando se verifica essa situação, sugere-se a avaliação do seu valor monetário e que se pague a metade do valor apurado. Se a solução não é do agrado, existe ainda a possibilidade do animal ser vendido pelo maior valor possível e o abade receber metade em moeda. Refere-se este pagamento ao gado bovino, suíno, ovino, aves domésticas, nomeadamente galinhas, frangos e patos e ainda mulas, burros e potros. Relativamente a estes últimos, o pagamento incide apenas após o segundo ano de vida, uma vez que antes desse período, não sobrevivendo longe das mães, não podem ser vendidos.

As décimas são cobradas sobre os enxames de abelhas, da cera e mel recolhidos, "assim no tempo da creesta ${ }^{63}$ como daquella que em elles fica quando morrem ou se vai o enxam"; sobre o leite, lã e queijos; sobre as hortaliças, castanhas e demais frutas, tanto as da época como as tardias ${ }^{64}$.

As tentativas de usurpação individa de dízima, ou o contrário, de tentativa de fuga ao pagamento adequado, são frequentes e, por essa razão, sujeitas a recomendações nas constituições sinodais. A exemplo disso, apresenta-se a constituição de D. Pedro Vaz Gavião que segue as indicações dos seus

${ }^{61}$ Sobre esta matéria vid. COELHO, Maria Helena da Cruz - O Baixo Mondego nos finais da Idade Média - vol. I. Coimbra: Faculdade de Letras, 1983, p. 382-398.

${ }^{62}$ GARCIA Y GARCIA, António (ed.) - Synodicon Hispanum II..., cit., p. 174-175; 391-394.

${ }^{63}$ Cresta refere-se à colheita do mel das colmeias tirando apenas parte dos favos.

${ }^{64}$ GARCIA Y GARCIA, António (ed.) - Synodicon Hispanum II..., cit.,, p. 173-175. 
antecessores reiterando a indicação, quando os donos de gado levam os seus animais para outras freguesias, do pagamento de metade da dízima nessas mesma freguesias e a outra metade à sua freguesia de origem ${ }^{65}$. O mesmo se aplica a quem for lavrar fora da sua freguesia ${ }^{66}$.

A primazia do cereal na alimentação medieval é unânimemente reconhecida. O pão é a base de alimentação, ao ponto de o próprio cereal assim ser designado, como acontece na legislação sinodal que "falla de como se ham de pagar os dízimos de pam". Recomenda-se, em relação ao pagamento da dízima do cereal, que os fregueses avisem os abades sobre a altura em que ceifam os campos, para que estes possam ir cobrar a sua parte, evitando que o cereal fique abandonado nas agras ${ }^{67}$ onde acaba por se perder. E caso o abade não o recolha, deve o camponês levá-lo para a sua eira, onde o abade o irá levantar ${ }^{68}$. Nas situações em que o terceiro ${ }^{69}$ da igreja não está presente na hora de recolher os frutos da terra, deve o freguês levá-los para o seu celeiro e posteriormente o terceiro, na companhia de duas pessoas idóneas, deverá dizimar e levar os frutos para o celeiro da igreja ${ }^{70}$. A igreja pode perder o direito à dízima, ou o lavrador pode dizimar ele póprio, caso a entidade eclesiástica não cumpra o prazo estabelecido para repartir a colheita ${ }^{71}$.

Quanto às dízimas pessoais, "que em algumas partes se chamam quartas e em outras conhecenças", variam consoante o mester: "o almocreve por cada besta doze reaes; e o carniceiro desta cidade ou das vilas xv, e das aldeias sete reaes $[\ldots]$ e a padeira doze reaes $[. .$.$] e os que tivessem canais,$ pescaria nos rios, que pagassem dízimo inteiro, e os outros pescadores que com artifícios tomassem trutas e outro qualquer pescado pagassem xii reaes; [...] e os moleiros pagassem dizimo inteiramente, e dos pisões quinze reaes; os lagareiros de azeite pagassem vinte reaes, item os que fizessem escudelas, talhadores, gamelas, ripas, trinchões, mesas, escadas, cestos, tabuado, arcas,

${ }^{65}$ Ibidem, p. $270-271$.

${ }^{66}$ Ibidem, p. 271.

${ }^{67}$ Campo cultivado ou cultivável.

${ }^{68}$ GARCIA Y GARCIA, António (ed.) - Synodicon Hispanum II..., cit., p. 175.

${ }^{69} \mathrm{O}$ mesmo que intercessor.

${ }^{70}$ GARCIA Y GARCIA, António (ed.) - Synodicon Hispanum II..., cit., p. 271-272.

${ }^{71}$ COELHO, Maria Helena da Cruz - O Baixo Mondego nos finais da Idade Média, cit., p. 385 . 
padiolas, bancos, carros, arados, para vender, xii reaes; e as regateiras dez reaes; os forneiros e forneiras, onde não fosse costume pagarem dízimo, pagassem $\mathrm{xv}$ reaes" ${ }^{\text {”2 }}$. Os valores variam também em função do tempo cronológico e da localização da igreja. Em data posterior, e noutra cidade, no caso Braga, apresentam-se outros valores para os mesmos ofícios: assim, deve o carniceiro da cidade ou vila pagar 40 reais e se for de fora 30 reais, caso o pagamento não se efetue, como é costume em alguns locais, com as línguas dos animais abatidos; o vinhateiro paga também 40 reais no caso de não ter bestas, caso contrário o preço aumenta em função do número de cabeças; os pescadores que têm canais ou pescam no rio as lampreias e outro pescado pagam sobre esses produtos e de toda a caça que fizerem; 20 reais é quanto pagam todos aqueles "que [...] fezerem escudellas, gamellas, talhadores, ripas, trichos, escadas, cestos, carrellas, padiollas ou bancos para vender, carros, grades, arados pêra vender ou os vendam", os que não têm mester e vivem como negociantes de gado devem pagar sobre o que compram e vendem. Os pagamentos devem ser feitos anualmente, no dia de S. João Batista ou nos 15 dias subsequentes. Todos são incentivados a cumprir com as obrigações da dízima, aos seus abades, sob ameaça de estarem em pecado mortal caso não cumpram as recomendações eclesiásticas ${ }^{73}$. A grande arma de coação por parte da Igreja é a advertência de excomunhão.

\subsection{Dirigidas}

\subsubsection{Ao clero}

A vivência quotidiana da época medieval está marcada pela vida agrária. Os campos cultivados - ou em pousio, para descanso - marcam os territórios e comandam o ritmo do homem medieval. Não cabe apenas ao campesinato a observância dos trabalhos da terra. Também o clero tem obrigações agrárias em relação às suas posses rurais. Os mosteiros e igrejas possuem as suas própria terras de cultivo, asseguradas pelos próprios ou entregues

\footnotetext{
${ }^{72}$ GARCIA Y GARCIA, António (ed.) - Synodicon Hispanum II..., cit., p. 268.

${ }^{73}$ Ibidem, p. 174-175.
} 
a procuradores sob rendas. Ora, nem sempre estes clérigos cumprem zelosamente com essas obrigações e não ficam livres de censura por parte dos seus superiores.

Uma vez mais, na legislação analisada, são acusados os abades de se ausentarem das suas igrejas não cumprindo com missas, horas e sacramentos e falhando ainda nos trabalhos agrícolas das searas, herdades e casais. Não lavram as terras, nem as mantêm cultivadas porque lá não vivem, nem as arrendam a clérigos ou leigos que delas se ocupem. Cabe pois, ao legislador, recomendar a todos os que nessa situação se encontram que, sob pena de multa, tratem das terras, ou mandem delas $\operatorname{tratar}^{74}$. De resto, apesar do grande número de escolas catedrais e conventuais no nosso território, é notória a falta de preparação atribuída aos clérigos, em diversas matérias, nomeadamente no que respeita aos procedimentos básicos para a celebração dos sacramentos. Um problema transversal às diversas paróquias e que leva os superiores a advertir os clérigos no sentido de conduzir a ação pelos cânones dos concílios ecuménicos da época. Em 1477, no decorrer do sínodo da arquidiocese de Braga, o arcebispo D. Luís Pires enfatiza esse problema e começa por advertir, em primeiro lugar, os clérigos pecadores ${ }^{75}$. Na mesma diocese, em outro sínodo, alertam-se abades e priores do arcebispado de Braga sobre algumas práticas em seus mosteiros. Acusados de não darem aos seus frades pão, broa e vinho de boa qualidade, estabelece e manda D. Gonçalo Pereira "que os abbades e priores lhis den sãs rações de bõo pam e de boa boroa e doo vinho communal [...] nas mesas no reffertorio assi ao jantar commo aa cena e [...] o al que lhis sobejar mandamos que cada hũu dos abbades et priores que o façam dar por Deus aos pobres e aos moazinhos e aos seus parentes pobres, tanto que nom sejam seus filhos"76.

As preocupações são outras, na diocese de Braga, um século depois. Trata-se agora de questões ligadas ao pão e vinho da Eucaristia. O arcebispo recomenda a todos os seus clérigos que vigiem os sacristãos, para que os alimentos usados na celebração eucarística - pão e vinho - sejam da melhor

${ }^{74}$ Ibidem, p. 48-49.

75 TEODORO, Leandro Alves - "O comprometimento moralizante dos sínodos portugueses entre os séculos XIV e XV”, in Portuguese Studies Review, 21 (1), 2013, p. 62.

${ }^{76} \mathrm{Ibidem}$, p. 51 . Ao não permitir que as sobras de comida sejam entregues aos filhos de abades e priores, admitem a existência de prole do clero. 
qualidade e colocadas nos mais limpos recipientes. Há, de facto, uma preocupação com a limpeza e pureza. E por esse motivo, o vinho deve ser puro "e que nom seja augapee nem outra mestura e que doutra guisa o nom tomem e que a auga seja linpa, pura e clara" e as hóstias devem ser feitas com "polme de farinha de trigo estreme e [...] se tal nom for, que a nom recebam, da qual farinha farom o polme nom com outra cousa senom com auga mui limpa, pura e clara em hũua escudela ou outro vaso novo, linpo, no qual nunca fosse fecta outra cousa" ${ }^{\prime 7}$.

Também sobre limpeza se lê nas constituições sinodais de D. Luís Pires. Recomenda este a limpeza das igrejas, em dias próprios - o sábado para que não fiquem nelas os frutos da dízima, pão ou pedra. Mais do que recomendações, determina as interdições, já antes indicadas, de não se comer e dormir nas ditas igrejas, nem mesmo os seus rendeiros ${ }^{78}$.

\subsubsection{Aos seculares}

O calendário litúrgico ordena a vida do homem medieval sobre vários aspetos, nomeadamente na determinação dos dias de descanso. E são bastantes esses dias. Para além de todos os domingos do ano, das festas de Cristo, dos dias de veneração à Virgem Maria, dos que honram alguns santos, acham-se ainda os dos oragos de cada igreja, totalizando cerca de uma centena de dias $^{79}$. Nestes, estão obrigados os fiéis cristãos, a não exercerem os seus ofícios, salvo se essas práticas resultarem em esmolas para os pobres e defavorecidos. É o que vem reforçar a constituição 50 do sínodo 11 do Porto, em que D. Diogo de Sousa expressa, de forma clara e determinada, a autorização aos pescadores que possuem licenças emanadas pelo arcebispado, para pescarem nos dias de guarda, uma vez que esse peixe - no caso sável - é para ofertar em esmola. Serve a presente constituição para salvaguardar essa autorização, uma vez que algumas pessoas embargam a pescaria "e os nom leixam pescar nos ditos dias ainda que lhes mostrem

\footnotetext{
${ }^{77}$ GARCIA Y GARCIA, António (ed.) - Synodicon Hispanum II..., cit., p. 95-96.

${ }^{78}$ Ibidem, p. 153 e p. 370.

${ }^{79}$ COELHO, Maria Helena da Cruz - A festa - a convivialidade..., cit., p. 147.
} 
nossos alvaraes de licença ou de nossos vigairos pera pescarem pera as ditas esmollas" ${ }^{\prime 0}$. Mostra, desta forma, a Igreja Católica, a sua postura caritativa e tolerante, de acordo com as suas determinações e leis. Contudo, a sua tolerância é limitada, sobretudo com os pecados dos seus fiéis cristãos. Os sete pecados capitais que perseguem a moral cristã e regem a vivência de todos os dias. Os pecados que a Igreja estipulou e nos quais se inclui a gula. O pecado que mais se prende com o corpo, com o alimento, com o que de mais básico tem o homem: a necessidade de comer e beber.

O pecado da gula é descrito no catecismo do sínodo celebrado no Porto, em 1496, como o "quinto peccado mortal [...] nelle peccam todos aquelles que trabalham por comer viandas de maior preço do que a seu estado covem, e asi os que buscam muita diversidade de manjares " e obviamente também aqueles que não cumprem os jejuns pois a "austinencia foi o primeiro mandamento que Deus deu a Adam". Pecam também "aquelles que comem mais do necesario". E serve para a bebida o mesmo que se indicou para a comida, sobretudo porque o beber "corrompe a natureza [...] traz os homẽs em grandes malles e pecados asi contra Deus como contra o prouximo e sua propria conciencia e honrra" 81 .

Concluídas estão as recomendações e advertências, finalizando com o pecado da gula. A igreja condena o desregramento, a procura desenfreada de satisfação através da comida. Os gulosos e lambareiros estão sujeitos à eternidade do inferno, não por acaso, frequentemente representado na iconografia religiosa com empreitadas culinárias, donde se infere que até os demónios infernais são dominados por desejos gastronómicos ${ }^{82}$.

\section{Conclusão}

Em resultado da análise à legislação sinodal, reitera-se o papel determinante da alimentação na época medieval, em particular na vivência quoti-

${ }^{80}$ GARCIA Y GARCIA, António (ed.) - Synodicon Hispanum II..., cit., p. 394-395.

${ }^{81}$ Ibidem, p. 408.

${ }^{82}$ LAURIOUX, Bruno - A idade média à mesa. Lisboa: Publicações Europa-América, 1989, p. 104. 
diana das relações sociais com a Igreja: nas disposições emanadas por esta, constrangindo ou coagindo comportamentos.

Não olvidando a restrita documentação em análise, permite-se retirar algumas ilações destas constituições sinodais, nomeadamente em relação ao poder emanado pela Igreja e à sujeição da sociedade a essas manifestações de força. A subordinação do campesinato é óbvia, apesar de algumas manobras de desvio, logo censuradas e repreendidas. Ainda que em vantagem social e melhores condições de vida, o próprio clero encontra-se sob o jugo hierárquico. Não obstante, as suas circunstâncias mais se assemelham às da nobreza, auferindo diversos direitos e dividendos.

É por força da lei que se constituem indicações rígidas quanto a dízimas e jejuns. Sempre sob a ameaça de excomunhões, multas e castigos, todos são instigados a cumprir estas obrigações normativas, bem como todas as demais situações que surgem no decorrer das constituições sinodais. Modelo de ordem, de regra e de preceitos, a Igreja regulamenta, dispõe e formula leis e recomendações. Ontem e hoje, essa necessidade permanente, por quem detem o poder, de controlar e impor um caminho. Ontem e hoje, a coexistência do cumpridor e do prevaricador!

Sob a pena que redige as constituições, lança-se a ideia de uma justa permanentemente travada entre o excesso e a austeridade: "A luta entre o Carnaval e a Quaresma" ${ }^{93}$ tantas vezes inglória.

\section{Fonte}

Synodicon Hispanum. II, Portugal, ed. de António Garcia y Garcia, Madrid, Biblioteca de Autores Cristianos, 1982.

\section{Bibliografia}

AGUILERA, César - História da alimentação mediterrânica, Terramar, Lisboa, 2001.

\footnotetext{
${ }^{83}$ Referência ao título da pintura de Bruegel o Velho.
} 
ARNAUT, Salvador Dias - A arte de comer em Portugal na Idade Média (Introdução a $O$ "Livro de Cozinha" da Infanta D. Maria de Portugal), Lisboa, 1986.

LAURIOUX, Bruno - A idade média à mesa, Publicações Europa-América, Lisboa.

CANTELAR RODRÍGUEZ, Francisco - El «Synodicon hispanum», espejo de la España medieval, Anuario de Historia de la Iglesia, 17, Universidad de Navarra, Pamplona, 2008, p. 337-341.

COELHO, Maria Helena da Cruz - "A festa - a convivialidade", in História da Vida Privada em Portugal, dir. de José Mattoso. A Idade Média, coord. de Bernardo Vasconcelos e Sousa, Lisboa, Círculo de Leitores, 2010, p. 141-169.

COELHO, Maria Helena da Cruz - O Baixo Mondego nos finais da Idade Média - Vol. I, Faculdade de Letras, Coimbra, 1983.

COELHO, Maria Helena da Cruz e HOMEM, Armando Luís de Carvalho - "A estruturação social", in Nova História de Portugal - Portugal em definição de fronteiras do Condado Portucalense à crise do século $X I V$, dir. de Joel Serrão e A. H. De Oliveira Marques, Lisboa, Editorial Presença, 1996, p. 165-383.

COSTA, AdelaIde Pereira Millán da - "O espaço urbano", in História da Vida Privada em Portugal, dir. de José Mattoso. A Idade Média, coord. de Bernardo Vasconcelos e Sousa, Lisboa, Círculo de Leitores, 2010, p. 24-39.

COSTA, Avelino de Jesus - "Sínodos e Constituições Diocesanas", in Acção Católica, vol. XXVI, 1941.

Dicionário da Idade Média, org. H. R. Loyn, Jorge Zahar Editor, Rio de Janeiro, 1990.

Dicionário de História de Portugal, Vol. II e III, dir. de Joel Serrão, Livraria Figueirinhas, Porto, 1992.

DUARTE, Luís Miguel - "Marginalidade e marginais", in História da Vida Privada em Portugal, dir. de José Mattoso. A Idade Média, coord. de Bernardo Vasconcelos e Sousa, Lisboa, Círculo de Leitores, 2010, p. 170-196.

GOMES, Saul António - "A questão judaica nos autores medievais portugueses”, Cadernos de Estudos Sefarditas, n. ${ }^{\circ}$ 9, 2009, p. 93-120. 
GONÇALVES, Iria - "A alimentação", in História da Vida Privada em Portugal, dir. de José Mattoso. A Idade Média, coord. de Bernardo Vasconcelos e Sousa, Lisboa, Círculo de Leitores, 2010, p. 226-259.

História da alimentação, dirig. por Jean-Louis Flandrin et Massimo Montanari, vol. I, Dos primórdios à Idade Média, vol. II. Da idade Média aos tempos actuais, Lisboa, Terramar, 1998, 2001.

MARQUES, A. H. de Oliveira - A sociedade medieval portuguesa. Aspectos da vida quotidiana, 4. . ed., Lisboa, 1982.

MARQUES, Maria Alegria, F. - "O saber e os saberes na legislação sinodal portuguesa da Idade Média", in História Revista, Goiânia, v. 18, n. 1, jan./jun (2013) 91-120.

PEREIRA, Isaías da Rosa - "A vida do clero e o ensino da vida cristã através dos sínodos medievais portugueses (séculos XIII-XV), in Lusitânia Sacra, Lisboa, t. 10, 1978.

— "Os sermões de André de Resende nos sínodos de Évora de 1534 e de 1565 e as falas de Francisco de Melo no sínodo de 1534", in Humanitas, Instituto Estudos Clássicos da Faculdade de Letras da Universidade de Coimbra, v. 43/44 (1992) 185-193.

RODRIGUES, Manuel Augusto - "Recensões e notas de leitura" in Revista de História das Ideias, vol. 5 (1984) 425-429.

TEODORO, Leandro Alves - "A regulação das solenidades religiosas nas terras portuguesas (sécs. XIV-XV)" in Confluenze, Università di Bologna, vol. 6, n. ${ }^{\circ} 1$ (2014) 61-73.

- "O comprometimento moralizante dos sínodos portugueses entre os séculos XIV e XV”, in Portuguese Studies Review, 21 (1) (2013) 7-18. 